\title{
Semiotic Analysis of the Visual Signs of Protest on Online Jordanian Platforms: Code Choice and Language Mobility
}

\author{
Ghazi K. Al-Naimat \\ Al-Hussein Bin Talal University, Jordan
}

\begin{abstract}
The political discourse of protesting which comprises carrying signs for clarifying demands and expressing feelings constitutes a significant area of study in the signs of online platforms within the linguistic landscape field. Taking as a case in point the Jordanian protest on May 30, 2018, a few examples of the signs of protest are analyzed using some aspects of visual semiotics, particularly the code choice. The study is grounded on both quantitative and qualitative data culled from online sources. The analysis of the data finds a variety of linguistic codes used in attaining different readerships: the standard form of Arabic as the official language in the country and in other Arab countries; Jordanian Arabic investigated as the device of speaking out the voice of the local audience; English viewed as the language of addressing the global audience; and the multilingualism occurrence as a significant feature in the corpus for achieving further readerships. These codes are largely motivated by other significant semiotic resources, including multimodality, font size, color relevance, and materiality practices. The study further views the signs of protest as a new trend of mobility, often considered a challenging notion to the territoriality of fixed signs in most linguistic landscape studies.
\end{abstract}

Index Terms — code choice, linguistic landscape, mobile signs, multilingualism, semiotic resources

\section{INTRODUCTION}

The studies on linguistic landscape (LL henceforth) have recently surpassed the focus of "public road signs, advertising billboards, street names, place names, commercial shop signs and public signs on government buildings" as primarily identified by Landry and Bourhis (1997, p. 25). Researchers of LL have not only studied the fixed signs in the geographical regions, but also extended their focus to include mobile or non-fixed ones, whether they are typically used in the visual scenery of streets (e.g., Scollon, 1997; Rozenholc, 2010; Coupland, 2010), or temporarily viewed on the signs of protest (cf. Kasanga, 2014; Ben Said \& Kasanga, 2016).

Thousands of inhabitants of Jordan across many industrial sectors on May 30, 2018 went on a rare nationwide protest against a proposed law of income tax. This event of protest demanded the protesters to carry out a persuasive campaign of influential political slogans, where there is more focus on the visibility of signs in media platforms. These social settings help to create a climate in which the visual of signs works as a medium for reflecting many socio-cultural aspects of the Jordanian society and further founding an area of significance and appeal on the national and global circumferences. The news agencies undeniably capture such signs to enrich their websites with more viewers and readers, but their advertising objectives gain more significance when considering the protesters' practices of shaping the visual format of their signs.

The focus in most studies of the protest discourse has been on the impact of languages on the audiences (e.g., Sonntag, 2003; Frekko, 2009; Bassiouney, 2012; Lahlali, 2014). This has been demonstrated in various regions, including the discourse of Gezi Park protests in Turkey for challenging the government dictatorial procedures (Seloni and Sarfati, 2017); the discourse of street protest banners and slogans in the local contexts of Iran, Serbia, Macedonia, and Ukraine (Bekar, 2015); the discourse of resistance in Nigeria for the deprivation of the community from sociopolitical reforms, largely reinforced by the social media networks (Chiluwa, 2012); the labor discourse in the new market economies of Central and Eastern Europe (Woolfson, 2006); and the discourse in women led-protests in the Nigerian Delta region as a result of the environmental degradation and shortage of community amenities (Ukeje, 2004).

The examination of the above studies amongst others discloses the fact that, the signs of protest within the visual semiotic principles have received little attention in the LL arena. A review of the literature finds that the signs of protest have been researched in few studies (cf. Kasanga, 2014; Ben Said \& Kasanga, 2016) as an attempt to incorporate such signs in the LL sphere. In particular, Ben Said and Kasanga (2016) who, based on the content analysis of the signs, identify common themes, topics, or issues across the protest acts of both the Egyptian and Tunisian revolutions during the Arab Spring. Kasanga (2014) further focuses on the code choice of languages displayed on the signs of protest for speaking up the Egyptian political messages during the same period. Kasanga's research is different from the present study in that he had investigated one semiotic perspective i.e., code choice, while this study intends to explore the data by means of more semiotic features to recognize the dominance of a language and to pinpoint its type of audience.

Accordingly, the present study falls in the scope of visual semiotics as developed by Kress and Van Leeuwen (1996) 
in which the grammar of visual design transfers the meanings of images and signs in the LL. The related signs are deemed resources, which individuals use, adopt, or design to make meaning through visual, written, or any multimodal semiotic modes (e.g., Thibault, 1991; Kress \& Van Leeuwen, 2001). The significance of the visual signs stems from the modes of how semiotic practices make the signs appear in the public spaces. Kress and Van Leeuwen (1996) maintain an important relation between the codes in the LL and their saliency based on the use of code size, upper-and lowercase letters, or font types in designing signs. Equally important is the informational value of visual signs that essentially relies on the arrangement of text codes, which contain three visual placements of linguistic elements: left-right, upperlower, and center-position.

Scollon and Scollon (2003) build on Kress and Van Leeuwen's (1996) visual semiotic framework, and generate code preference system grounded in code size and placement. Their argument is founded on the fact that the multiple codes on a sign usually show a preferred code since they are not possibly located in the same position. Therefore, the preferred code representing the main language is typically placed at the top, left, or central position of a sign, while the less preferred code representing the minor language is placed at the bottom, right, or other surfaces of a sign. In cases where size and order show conflicting preferences, size outweighs the order (Scollon and Scollon, 2003, p. 120). Huebner (2006, p. 55) elaborates on Scollon and Scollon's (2003) approach of code preference, and argues that the position of the different codes and the size of font are the prime features used to detect the dominant language on a sign, which are also largely manipulated by other visual elements such as "color, images, and the amount of texts". However, there is no consensus amongst researchers of LL with regard to which colors are realized as dominant on signs; the idea is to discuss their roles in supporting the choice of a certain code on multilingual signs.

The multimodality semiotic principles also relate greatly to the code choice, which concern the interrelationship between the linguistic and non-linguistic components of the sign to make the message as persuasive as possible (e.g., Beasley \& Danesi, 2002; Seals, 2013). In this regard, Kress and Van Leeuwen (2001) maintain a contiguous connection among the visual, verbal, and written features of the signs for communicating their social meanings. These semiotic resources have been applied to fixed (cf. Backhaus, 2007; Al-Naimat, 2015) and mobile signs which among others include bills, stamps, tickets (Sebba, 2010), banknotes (Hawkins, 2010), T-shirts (Coupland, 2010), and billboards (Stroud and Mpendukana, 2009).

The focus in this study is on investigating the semiotic characteristics of the signs of protest, occurring on online Jordanian platforms, in light of an orderly methodological categorization of their textual and visual elements to reach out the linguistic practices of addressing different audiences. Meanwhile, the related features tend to explore other cultural perspectives, particularly languages mobility and their socio-political associations.

\section{SOCIOLINGUISTIC CONTEXT OF JORDAN}

Exploring the languages used in Jordan cannot be overlooked due to their significance in analyzing the potential codes apparent on the existing signs. Arabic and English are the two major languages spoken in Jordan. Arabic, which is the official language used in Jordan, takes three different forms: Classical Arabic (CA), Modern Standard Arabic (MSA), and Jordanian Arabic (JA). CA is used as the language of Qur'an and Hadith; the recitation of Qur'an verses while praying or giving sermon characterizes its use. MSA, which is derived from CA, is the language of writing and formal situations. It is often used in the language of modern journalism, newspapers, and news reports (Ryding, 2005). JA occurs extensively in daily life conversations especially among family members and friends and, therefore, it distinguishes Jordanians from other Arabic-speaking communities.

As regards English, it has gained ground in all the local sectors, including education, business, and science technology. English in Jordan, as elsewhere, is part of the globalization, in which people can engage in the world through the cultural communication, science, or technology.

Some other European languages, too, including but not limited to French, Italian, and Spanish have been a place of interest to many Jordanians for private commercial and cultural reasons. The Chinese language has been also given an advantage, where it identifies a very developed country in recent decades due to the fact that it has the fastest growing economy in Asia.

\section{Methodology}

A combination of quantitative and qualitative approaches (e.g., Ben-Rafael et al., 2006; Gorter, 2009; Lai, 2012) has been implemented in the present study. Recent trends of LL studies have tended more toward a qualitative or combined approach for exploring the semiotic perspectives of signs (Gorter, 2013, pp.198-201). The approach maintains a sense of cross-referencing, where the language use is contextualized and explored by quantitative data and then its impressionistic conclusions are hindered by qualitative analysis (Blackwood, 2015).

The signs in most LL studies have been determined as visible linguistic objects that mark a specific public space (e.g., Reh, 2004; Ben-Rafael et al., 2006; Backhaus, 2007). In contrast, this study views the signs used in the protest scene as illustrative examples of mobile signs versus fixed ones. The analytical approach for such signs borrows large insights from the semiotic principles. They are, as discussed above, undoubtedly leading tools for breaking up the figurative meanings of the prevailing languages on signs (cf. Kress \& Van Leeuwen, 1996; Scollon \& Scollon, 2003). 
The study draws on signs collected from a variety of online local, national, and global platforms. They include newspaper agencies such as Saraya, Ammon, Khabrni, Roya, Sawaleif, Ajman, Arabic and English BBC, France 24, CNN, Arabic and English Al-Jazeera, and Al-Arabiya, as well as the social media pages. Even though not all the platforms are spatially located in Jordan, the key point for the data is to consider what they include or show about the local protesting scene. While collecting and categorizing the signs, there have been some methodological challenges regarding founding a linguistic correlation between the type of language on signs and the source where it was observed. Nevertheless, due to the frequent incidence of the same sign across many news pages, there appears little tendency for developing any area of interest like that and, therefore, the corpus of the study is limited to the languages of signs, as discussed in the next section.

As such, the online platforms are the data sources for the study as they offer boundless option to write new letters and analysis and, thus, they could point to the signs of protest, especially during an important political event in Jordan i.e., the opposition of people to the recent decisions of the government.

The majority of signs feature textual languages alongside images. Permission has been granted by the news page owners. Photographs without texts were also eliminated from the collection. This permits exploring the symbolic interpretations of languages in relation to the potential presence of images, as indispensable semiotic elements to the textual meanings of signs.

The collection considers all visual signs created essentially by protestors, regardless whether they are involved in the act of protest or displayed on their businesses. The signs, in case found repeated in the sources, are excluded. To this end, the corpus of the study is obtained from 82 signs used by many Jordanian protesters and caught from different online platforms i.e., a relatively small but specialized corpus has been compiled for the current study.

\section{RESULTS}

Beginning with the quantitative part of the research, all signs as presented in Table 1 were coded according to monolingual i.e., MSA, JA, and English; bilingual i.e., JA-MSA, JA-English, and JA-Chinese; and multilingual i.e., JA-MSA-English signs.

TABLE 1

LANGUAGES ON MONOLINGUAL AND MULTILINGUAL SignS ON ONLINE JORDANIAN PLATFORMS

\begin{tabular}{lcc}
\hline Type of Linguistic Signs & Number & Proportion \\
\hline MSA & 41 & $50 \%$ \\
JA & 14 & $17 \%$ \\
English & 4 & $5 \%$ \\
JA+ MSA & 11 & $13 \%$ \\
JA+ English & 4 & $5 \%$ \\
JA + Chinese & 1 & $1 \%$ \\
JA + MSA + English & 7 & $9 \%$ \\
Total & 82 & $100 \%$ \\
\hline
\end{tabular}

As noted in the table, the majority of signs include monolingual MSA. It comprises 41 signs (50\%). MSA appears to play a great role at the local and national levels. It is the very language that is read and understood not only by Jordanians, but also by people in other Arab countries. The expressions and phrases shown on MSA signs have exhibited a variety of statements as listed below:

(1) a. aleStda? Sla almwat'in xat' ahmar.

b. 'Assault on the citizen is a red line.'

(2) a. maS alwt'an walmwat' in.

b. 'With the homeland and the citizen.'

(3) a. la liqat' $\subseteq$ arwa:tib, fai?nna wra? kul ratib ?usar, itqu: allah.

b. 'Not to cut off salaries, behind every salary are families, fear God!'

(4) a. ad'rib alyau:m li?aSi:fa yadan lali qanu:n ad'areebah.

b. 'I strike today to live tomorrow, no for the tax law.'

(5) a. d3ayb almuwat' in laysa huwa alhall.

b. 'The pocket of the citizen is not the solution.'

(6) a. la liPid'Sa:f alqudrah affira:Piyyah lilmuwat'ini:n.

b. 'Not to weaken the purchasing power of citizens.'

JA-only signs are found on about $17 \%$ of all signs (14 signs), while the joint JA ones alongside other codes such as English, Chinese, and MSA occur in $28 \%$. Taken the two proportions together, they demonstrate the significance of JA in addressing the majority of Jordanians. JA is the ideal linguistic carrier for reflecting Jordanians' views and concerns. Likewise, the protestors seem to attribute a great role to their audience and so choose a mutually intelligible language among the Jordanian viewers for seeking a potential form of sympathetic assistance. Examples of JA include: 
(1) a.ma badna tayyi:r Psma:?. badna tayyi:r anhd3

b. 'We do not want to change the names. We want to change the approach.'

(2) a. hil San ratibi.

b. 'Leave my salary alone.'

(3) a. bis'rif Sla Oalath awla:d wahukumah.

b. 'I spend lots of money on three children and a government.'

(4) a. xalas bikaffi: ðabaћtu:na.

b. 'Enough! You have slaughtered us.'

MSA and JA often engage in most bilingual and multilingual signs as demonstrated in Table I. On the one hand, JA is often combined with MSA, English, or Chinese in the bilingual signs. On the other hand, it occurs in multilingual signs comprising JA, MSA, and English. Nevertheless, all the existing languages are analyzed using code choice alongside other cooperative semiotic resources.

\section{Code Choice}

To pursue the type of audience targeted in each set of signs presented earlier, the different languages used on the signs are analyzed and sampled with figures according to the dominant code choice of a language, no matter the data is analyzed as mono-, bi, or multilingual signs.

\section{Modern Standard Arabic}

MSA, which constitutes $50 \%$ of all signs, is the prevalent monolingual code in all signs of the protest context. Table 1 provides a numeric overview of the number and proportion of MSA signs. The protestors seem to realize the significance of using MSA in addressing the official authorities in the country and deploying a profound impact on the public, too. This set of signs shows that the main messages are typically written and demonstrated in a large red code as

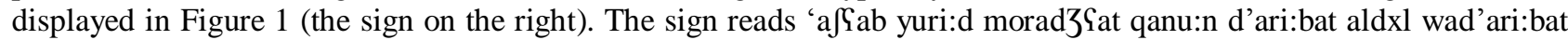
almabi:Sat' meaning 'People want to review the income tax law and sales'. The sign illustrates a dominant semiotic effect of the color; the striking message of the codes 'd'ari:bat adxl wad'ari:bat almabi:Yat' (the income tax law and sales) is displayed in red, whereas other codes are written in blue. In this respect, I argue that the use of the red color well exhibits the Jordanians' strength and determination on their demands, which aim to refuse the imposition of the new taxes.

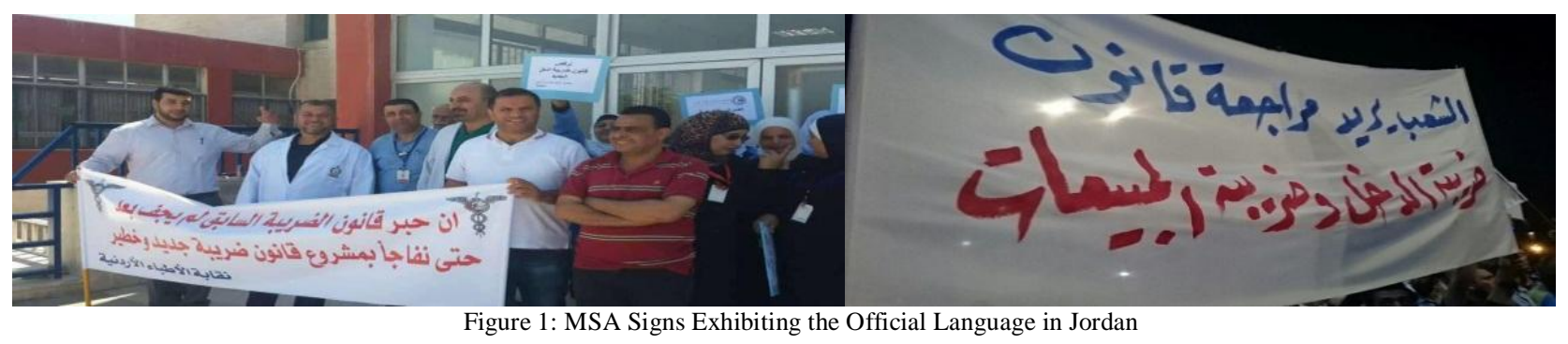

There also seems to be a correspondent relationship between the standard form of Arabic and the type of demonstrators involved. In many instances, the corpus shows that professionals comprising doctors, engineers, lawyers, or nurses are the protestors who carry signs written in MSA. The sign on the left (Figure1) reads '?inna hibra qanu:n ad'ri:bah assabiq lam yadZiffa baSd hatta natafadZa? bimafru:ৎ qa:nu:n d'ari:bah dZadi:d wa?axt'ar' meaning 'The ink of the former tax law has not dried up to be surprised by a new and more dangerous tax bill'. The codes, in this sign, are written in a highly abstract form of Arabic in terms of its syntactic structure and the choice of Arabic vocabulary. These linguistic practices are further emphasized through concluding the text with the phrase 'naqa:bat al?at'ibba:Palurduniyyah' meaning 'Jordan Medical Association', highlighting the value and importance of the language in ways conformed to the protestors' high-ranked professions in Jordan.

It should be noted at this point that all speakers of Arabic-with different educational backgrounds, classes, and geographical territories- view MSA as a high status variety in contrast to the JA. As such, the presence of MSA plays a vital role in nurturing the current category of signs whose prestigious and official associations can widen the ran ge of communication with people in other Arab countries.

\section{Jordanian Arabic}

The use of JA, as illustrated above, comprises the fact that the protestors intend to surpass the official ways of addressing those in authority and pursue more voices, assistance, and appeals from the public support. It seems highly plausible that Jordanians running the protest campaign necessarily seek to include a great proportion of JA, whether it appeared separately $(17 \%)$ or jointly with other languages $(28 \%)$. This joint data furthermore points to the ways in which the regional Arabic is the most spoken language in the country.

The linguistic components of the JA expressions and phrases feature several forms of acts of request and an insightful sense of complaint. Examples include 'thabahtu:na' meaning 'You have slaughtered us'! and 'fa:rik, s'a:r badha Pid'ra:b' meaning 'Take part, it demands protesting', all of which aim to speak out the local audience's loud voices due to their awareness of the language i.e. JA. Furthermore, the great impact of the local language is realized through the 
employment of a variety of semiotic practices in shaping the signs in question. As shown in the sign on the left (Figure 2), the protestors seem to write 'm? 9 na: $\int$ (meaning 'We have nothing') in a much larger font size, thus showing visual prominence and making the relevant language a medium through which the message is conveyed to the local people as well as the official decision makers.

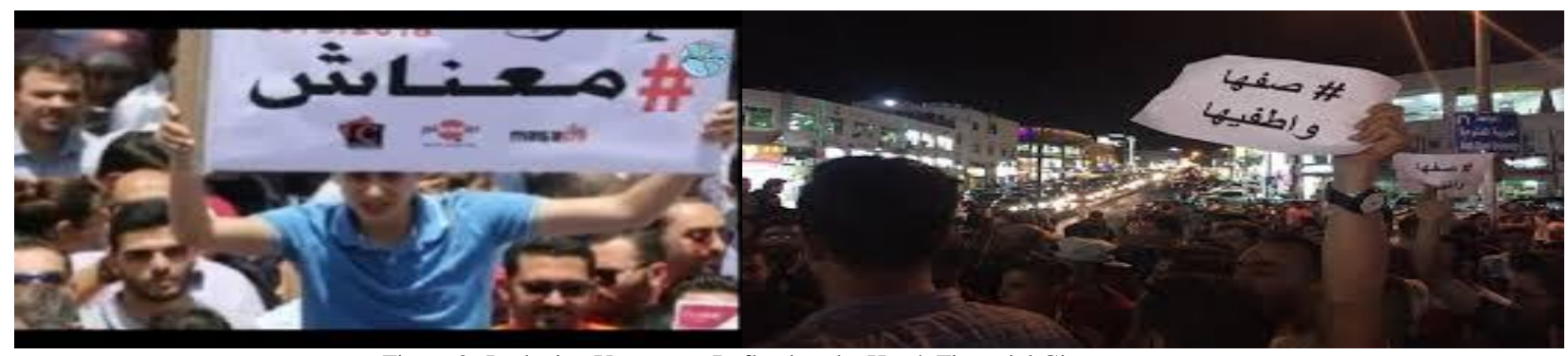

Figure 2: Jordanian Utterances Reflecting the Harsh Financial Circumstances

However, this Jordanian utterance, which occurs more than four times in the corpus, turns into a common and intelligible slogan among many Jordanians. It consists of the subject 'we', the verb 'have', and the negative particle 'nothing', , all integrated in a single utterance 'mPSna: $\int$ to seek an in-depth effect on the part of Jordanians' political viewpoints. Practically, 'mPSna: $\int$ is used later as a shared hashtag among many Jordanian users of Facebook for voicing their discontent and frustration about the economic decisions of the government.

In relation to this, the sign materials reflect important social positions associated with the protestors' messages (viz., Al-Naimat \& Alomoush, 2018). The majority of JA signs is printed or hand-written by normal people on paper or cartoon board as seen in the sign on the right (Figure 2), which reads 's'uffha wit'fi:ha' meaning 'pull it off' i.e. the idea is to demand Jordanians to stop their cars by the sides of roads. In the same vein, JA is printed on paper in part for showing the Jordanians' possible hard economic circumstances. Unlike the above signs, whose large codes are designed on good-sized plastic or cloth board, the current ones are normally molded on small paper materials.

English

Although numerically a category of peripheral position is dedicated to English, the quantitative data opposes its prominence in the Jordanian LL for indexing encouraging social meanings (Al-Naimat, 2015; Alomoush, 2015). For these reasons, I argue that the English signs earn their place in the current typology of the study.

Protestors involved in the protest could find it inadequate to write their posters, banners, or placards in Arabic where the requests remain local and achieve little impact. Alternatively, they feel the signs demonstrated in English acquire a globalism and so attract the international media i.e., English expands the global occurrence and circle of the signs to disseminate their messages and voices far and wide.

Even though the signs in this sub-group are generally hand-written on paper materials, the status of English increases their effectiveness and make it an appealing language to the global understanding to Jordanians' dissatisfaction and frustration. Prominent among all the examples is 'WE STAND Because WE CARE!! It's Kenzy Future' as manifested in Figure 3, it contains large uppercase letters in size for emphasizing the profound meanings of the protestors' intended messages regarding the great concerns about the future of the country. The relevant messages, with the use of English, certainly acquire a wider communication with people worldwide.

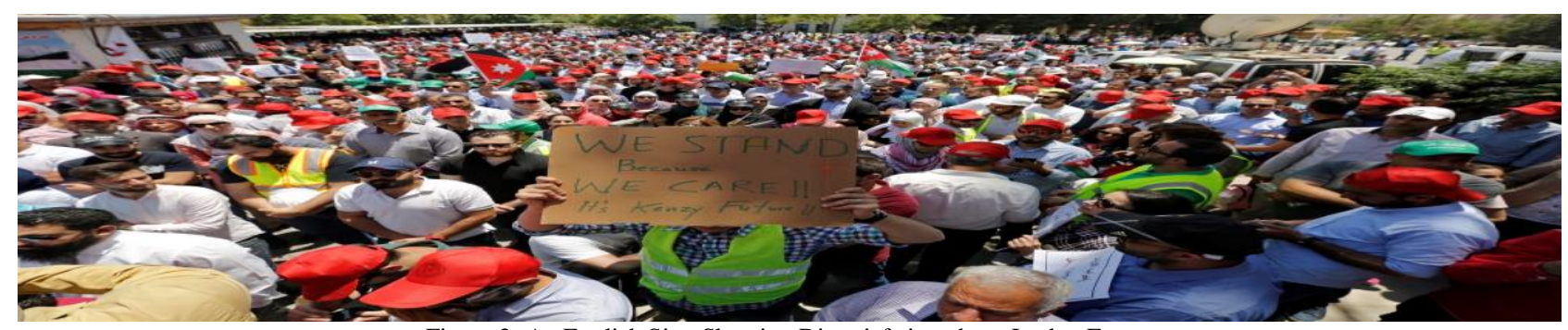

Figure 3: An English Sign Showing Dissatisfation about Jordan Future

Furthermore, English lends itself to the protest context for its excessive function in the identification of economic problems and offering solutions. This simultaneity is echoed in Figure 4, an English sign illustrating a global economic target. The sign reads 'Economic Prosperity requires flushing Cash into the market, NOT bankrupting people \& complaining by more taxes. Jordan STRIKE 30 May 2018.' From the point of view of code choice as articulated by Scollon and Scollon (2003), the carrier of the sign, a representative sampling of protestors, appears to use the capitalized lettering in the words Economic, Prosperity, Cash, NOT, and STRIKE as semiotic practices featuring a great status to the economic problems in Jordan, and how they could be solved in ways other than taxes. Other related

${ }^{1}$ This is in accordance with the author's own translation. 
semiotic resources such as the handwriting mode and the use of paper do not show any effect on the visibility of the texts. More importantly, a key role is devoted to English for drawing attention of the global audiences.

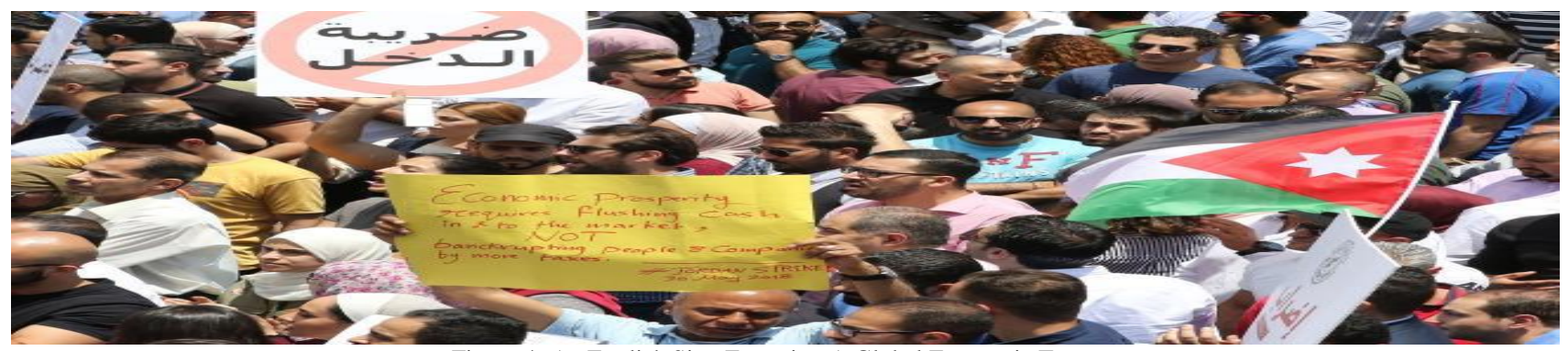

Figure 4: An English Sign Featuring A Global Economic Target

However, the present act of protest is often thought of as a standing means of calling for conditions where language practices demand the use of English as a combined language of the new globalized economy (Blommaert, 2010), wherein English with its global values has prompted the economic responsibilities of various international corporations worldwide. The carrier of the sign (Figure 4) accordingly intends to address the global economic trends to look and find real solutions to the crisis of his country. Overall, the use of English in this place suggests that the protestors believe in the current period of the global economic expansion pointing to the potential of sharing the local financial crisis.

\section{Multilingualism}

The occurrence of multilingualism in online platforms scene is detected. Multiple languages in the LL often appear to compete with each other for code preference (e.g., Gorter, 2006; Alomoush, 2015). As shown in Table 1, the multilingual sign includes the presence of JA alongside English, Chinese, or MSA. A prime example is realized from the overall structure of the textual components in Figure 5 (the sign on the right), which reads '?ana muwa:t'in urduni mu $\mathrm{ATM}$ ' meaning 'I am a Jordanian citizen, NOT ATM'.

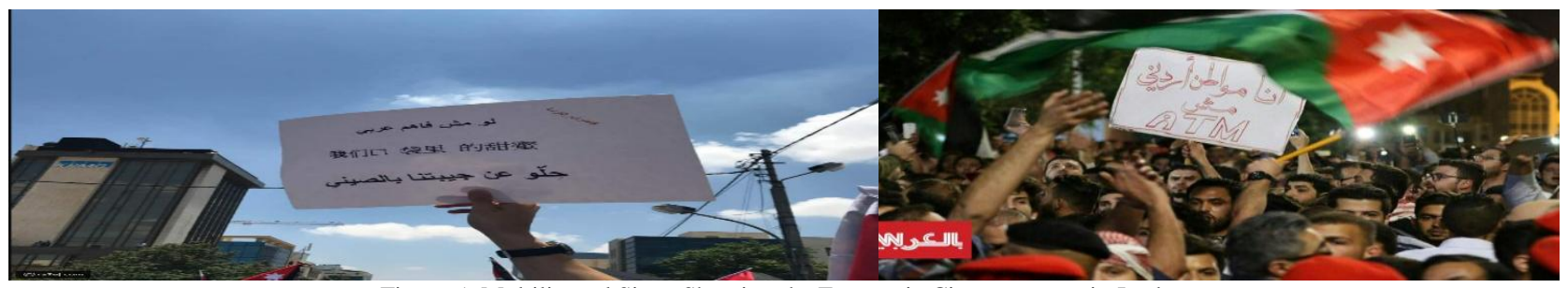

Figure 5: Multilingual Signs Showing the Economic Circumstances in Jordan

Even though the letterings of both MSA and JA are placed on top position, the font size of the English text makes it gain a more salient position (cf. Scollon and Scollon, 2003) and so establishes a place of attention and uniqueness compared to other codes.

The multilingual writing here reveals two crucial tenets about the two languages: Arabic and English. On the one hand, Arabic, which is the language of local audience, contains the idea that the protestors are primarily inhabitants of Jordan, and that NOT ATM is written for conveying feelings of complaint and discontent with the government decisions. On the other hand, English reveals some symbolic global meanings rooted in the fixed form of ATM letters worldwide, constructing a place of readership for the speakers of both Arabic and English (e.g., Blommaert, 2010; Al-Naimat, 2015). In particular, the English variety of $A T M$ is repeatedly used among Jordanians and has become part of the communicative repertoire of many speakers of Arabic. Therefore, the protestors could assume its perception on the part of local people. As Makoni and Pennycook (2006) note, the global languages can be understood in the local communities, in case that "to understand the language use, we need to incorporate local language" (p.20).

An equal symbolic message occurs in the sign on the left (Figure 5) whose impact appears to be refined through the choice of JA. The sign reads 'law mu fa:him Sarabi, hillu San d3i:bitna bis's'i:ni' meaning 'If you do not understand Arabic, leave our pockets alone in Chinese'. It seems that the protestors are aware that Chinese could not be understood in Jordan based on the small fonts of Chinese codes, which are further translated and written in large fonts of Arabic. However, despite the little use of Chinese in Jordan, its occurrence in the protest scene might be related to the very reason of making fun of it as a hard and complex language. At the same time, the language itself could be perceived as an exciting semiotic medium for exhibiting Jordanians' persistence on their demands.

Taken into consideration the two languages, it is not much the specific use of Chinese or English. More significantly, it is the very particularity of using a language that is not only foreign, but also kindles extremely adequately the views of the public, not least its adjacency alongside the Arabic texts, all these languages coalesce to subsidize the symbolic construction of multilingualism in the Jordanian protesting context.

\section{Other Cooperative Semiotic Resources}

These significant semiotic trends are studied in the frame of multimodality, in which there is a potential sense of 
interrelationships between the textual components of signs and their graphic designs such as images, fonts, and color (Kress and Van Leeuwen, 1996, p. 81). The data shows specific signs with certain texts alongside some drawings or images as amalgamated semiotic structures in meaning-making. For instance, the sign on the right (Figure 6) illustrates three visual elements: the MSA 'Pid'ra:b 30 Payya:r' meaning '30 May strike' at the top left, the map of Jordan depicted as a cow giving milk, and JA 'd'all Pifi mahalabtu:h' meaning 'Is there anything left you did not milk!!'2. In this context, the protestors aim to widen their political messages to diverse layers of people in Jordan and worldwide; particularly the drawing of milk is extremely appropriate to express the idea that most economic resources in Jordan have been stolen in much the same way the cow is milked.

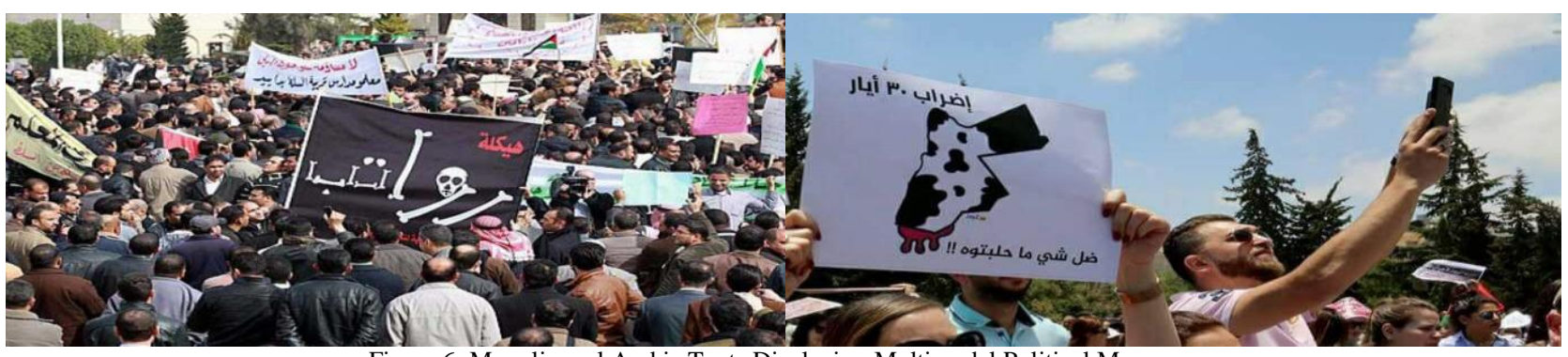

Figure 6: Monolingual Arabic Texts Displaying Multimodal Political Messages

This particular set of signs displays a variety of semiotic components, which contribute to understanding the symbolic political views by considering the overall visual of signs. Jaworski and Thurlow (2010, p. 2) focus on this semiotic aspect in which "the way written discourse interacts with other discursive modalities: visual images, nonverbal communication, architecture and the built environment". As a result, the multimodal sign in the map of Jordan could have little impact with no focus on the image, which is semiotically a fundamental element in the text.

The visual ways in which images articulate and shape the political messages also occur in the sign on the left (Figure 6), where the Arabic word reads 'haykalah' meaning 'economic restructuring'. The word is more likely to be perceived through drawing another one 'rawa:tib' meaning 'salaries'; it is represented in some form of bones for reflecting the low economic circumstances of the country. From the semiotics perspective, although the word 'haykalah' is printed in red for indexing danger and threat connotations and placed on a high position, the word 'rawa:tib' in its sizeable multimodal arrangement appears to gain more attention. This has been also enhanced through the choice of the black background on which the multimodal text is molded as another good reference to the financial situations in Jordan. To this end, the semiotic multimodality relations appear to make the protestors' messages obtain more readerships and, therefore, the symbolic meanings are definitely publicized i.e., there is an erosion of the Jordanians' pay.

\section{DisCUSSION AND CONCLUSION}

In this study, I have endeavored to apply the frame approach of visual semiotics, in particular code choice, font size, color relevance, materiality, and multimodality on the language of protest in order to explore the protestors' linguistic diversity in addressing different segments of audiences. This exploration in conjunction with the code choice complements the LL symbolic functions proposed by Spolsky and Cooper (1991). They proposed necessity condition as a requirement for protestors to choose a language comprehensible to the viewers. This goes with the use of MSA and JA because of their extensive use in formal speeches and daily life activities, respectively. The global drives of both English and Chinese seem to unveil some personal attempts to be identified in the data, though English is widely used in Jordan.

However, the use of English and Chinese in the protest context quite goes away from the traditional manner of the LL studies where the language complements the idea of "in place meanings of signs" (Scollon and Scollon, 2003, p. 1) i.e., the approach that the meanings of signs rely on where and when they are positioned in a certain territory. These cultural and physical backgrounds do not have their places in the existing signs. The concept of place in the LL has disappeared from the protest scene. Instead, it involves non-fixed signs for devoting more significance to the motion of signs in the LL, calling for some political views awakened in the period of protest. This outcome applies to MSA, which is analyzed as a code understood to both Jordanians and other speakers in the Arab world as well as other foreigners recognizing the temporariness and transience perspectives of languages.

Without doubt, English conveys a mobility role worldwide, where it is the individual global language "without precise geographical boundaries or clear coordinates" (Saraceni, 2010, pp. 1-2). This has been observed in the English signs underlying objectives for speaking to the international incorporations to take their responsibilities toward the economic circumstances in other countries such as Jordan. Chinese is no exception another dominant foreign language (after English) according to the increasing number of its learners worldwide (viz., Parisot, 2013), making it another linguistic instrument of language mobility on its competing economic power to English global forces. It is true that Chinese is used for comic and fun reasons in this place, but its presence springs from the point that it symbolizes a

\footnotetext{
${ }^{2}$ In the Jordanian context, the verb 'milk' is negatively used at the time the resources of the government are exploited.
} 
global economic power, whose language permits the mobility of the protestors' views in other niches.

In addition to the striking role of languages, the visibility of the signs in many Arabic and worldwide news agencies has clearly played a great part in circulating the languages political dimensions. Thus, the understandability of languages can better work in English or multilingual signs. Arabic codes also gain global readership because of their juxtaposition to English, or the visual multimodal structure of signs.

Based on these considerations, it should be emphasized that the notion of the language in place in its geographical and physical space becomes less relevant to mobile signs meaning-making, demanding the linguistic landscapers to assess the signs of protest according to a criterion less reliable on the territoriality. This finding seems to be synonymous with that of Kasanga (2014) who demonstrates that the investigation of the protest context provides new perspectives of re-considering the concept of territoriality of the fixed signs in LL studies. Also important to note is that the mobility of languages has been settled through the frequent semiotic features. For instance, the code choice in the English lettering ATM reveals more salience and importance to the entire multilingual text of the sign (Figure 5).

The analysis of the signs of protest, which falls within the LL arena, contributes to the semiotic guiding principles (e.g., Kress and Van Leeuwen, 1996; Scollon and Scollon, 2003; Huebner, 2006), in particular, in identifying different readerships on the local and global levels and exploring a range of symbolic cultural, socio-political, and economic associations, despite their transient and ephemeral nature. The semiotic principles carried out in analyzing the related languages have shown the great importance of such a special set of signs in terms of both the code choice and language mobility. This line of research contributes to the point that the languages of protest is made in some way to gain the mobility image, no matter through the official language in the country, multilingual writings, the use of English, or the multimodal design of signs.

\section{APPENDIX}

\begin{tabular}{|c|c|}
\hline \multicolumn{2}{|c|}{ Consonant phonemes of Jordanian Arabic } \\
\hline$?$ & voiceless glottal stop \\
\hline $\mathrm{b}$ & voiced bilabial stop \\
\hline $\mathrm{t}$ & voiceless interdental stop \\
\hline$\Theta$ & voiceless interdental fricative \\
\hline ds & voiced palatal fricative alveolar \\
\hline$\hbar$ & voiceless pharyngeal fricative \\
\hline $\mathrm{X}$ & voiceless velar fricative \\
\hline d & voiced dental stop \\
\hline ð & voiced inter-dental fricative \\
\hline $\mathrm{r}$ & voiced alveolar tap \\
\hline $\mathrm{Z}$ & voiced dental fricative \\
\hline S & voiceless dental fricative \\
\hline $\int$ & voiceless palatal fricative \\
\hline s' & voiceless fricative alveolar \\
\hline$t^{\prime}$ & voiceless emphatic stop \\
\hline ð' & voiced emphatic fricative \\
\hline d' & voiced emphatic stop \\
\hline$\varsigma$ & voiced pharyngeal fricative \\
\hline Y & voiced velar fricative \\
\hline $\mathrm{f}$ & voiceless labio-dental fricative \\
\hline$q$ & voiceless uvular stop \\
\hline $\mathrm{k}$ & voiceless velar stop \\
\hline 1 & voiced lateral alveolar \\
\hline $\mathrm{m}$ & voiced bilabial nasal \\
\hline $\mathrm{n}$ & voiced alveolar nasal stop \\
\hline $\mathrm{h}$ & voiceless glottal fricative \\
\hline $\mathrm{W}$ & voiced bilabial glide \\
\hline $\mathrm{y}$ & voiced palatal glide \\
\hline \multicolumn{2}{|c|}{ The Arabic vowels used in the study } \\
\hline i: & High front long vowel \\
\hline $\mathrm{i}$ & High front short vowel \\
\hline $\mathrm{u}:$ & High back long vowel \\
\hline $\mathrm{u}$ & High back short vowel \\
\hline a: & Low back long vowel \\
\hline $\mathrm{a}$ & Low back short vowel \\
\hline
\end{tabular}




\section{REFERENCES}

[1] Al-Naimat, G. (2015). Brand names in the linguistic landscape of Aqaba, Jordan. Unpublished doctoral dissertation, University of Liverpool, Liverpool, UK.

[2] Al-Naimat, G. \& Alomoush, O. (2018). The Englishization of materiality in the linguistic landscape of a southern Jordanian city. Arab World English Journal, 9(4), 88-107.

[3] Alomoush, O. (2015). Multilingualism in the linguistic landscape of urban Jordan. Unpublished doctoral dissertation, University of Liverpool, Liverpool, UK.

[4] Backhaus, P. (2006). Multilingualism in Tokyo: a look into the linguistic landscape. In D., Gorter (Ed.), Linguistic landscape: a new approach to multilingualism. Clevedon: Multilingual Matters, pp.52-65.

[5] Bassiouney, R. (2012). Politicizing identity: code choice and stance-taking during the Egyptian revolution. Discourse and Society,23(2), 107-126.

[6] Beasley, R. \& Danesi, M. (2002). Persuasive signs: the semiotics of advertising. Berlin-New York: Mouton de Gruyter.

[7] Bekar, M. (2015). Space, language and power: the rhetoric of street protests. Sociological Review, 49(3), 337-348.

[8] Ben Said, S. \& Kasanga, L. (2016). The discourse of protest: frames of identity, intertextuality and interdiscursivity. In R. Blackwood, E. Lanza, \& H., Woldermariam (Eds.), Negotiating and Contesting Identities in Linguistic Landscapes (68-83). London: Bloomsbury.

[9] Ben-Rafael, E., Shohamy, E., Amara, H., \& Trumper-Hecht, N. (2006). Linguistic landscape as symbolic construction of the public space: The case of Israel. International Journal of Multilingualism, 3(1), 7-30.

[10] Blackwood, R. (2015). LL explorations and methodological challenges. Analysing France's regional languages. Linguistic Landscape, 1(2), 38-53.

[11] Blommaert, J. (2010). The Sociolinguistics of Globalization. 2nd ed. Cambridge: Cambridge University Press.

[12] Chiluwa, I. (2012). Social media networks and the discourse of resistance: A sociolinguistic CDA of Biafra online discourses. Discourse \& Society, 23(3), 217-244.

[13] Coupland, N. (2010). Welsh linguistic landscapes "from above" and "from below". In A. Jaworski \& C. Thurlow (Eds.), Semiotic Landscapes: Language, Image, Space (77-101). London and New York: Continuum.

[14] Frekko, S. (2009). Signs of respect: neighborhood, public, and language in Barcelona. Journal of Linguistic Anthropology, $19(2), 227-245$.

[15] Gorter, D. (2006). Further possibilities for linguistic landscape research. In D. Gorter (Ed.), Linguistic landscape: a new approach to multilingualism (1-9). Clevedon: Multilingual Matters.

[16] Gorter, D. (2009). The linguistic landscape in Rome: aspects of multilingualism and diversity. In R. Bracalenti, D. Gorter, C. I., Santonico Fer-rer, \& C. Valente (Eds.), Changes in the linguistic landscape (15-55). Rome, Italy: Edup SRL.

[17] Gorter, D. (2013). Linguistic landscapes in a multilingual world. Annual Review of Applied Linguistics, 33, 190-212.

[18] Hawkins, S. (2010). National symbols and national identity: currency and constructing cosmopolitans in Tunisia. Global Studies in Culture and Power, 17(2/3), 228-254.

[19] Huebner, T. (2006). Bangkok's linguistic landscapes: environmental print, codemixing and language change. In D., Gorter (Ed.), Linguistic landscape: a new approach to multilingualism (31-51). Clevedon: Multilingual Matters.

[20] Kasanga, L. (2014). The linguistic landscape: mobile signs, code choice, symbolic meaning, and territoriality in the discourse of protest. International Journal of the Sociology of Language, 230: 19-44.

[21] Kress, G. \& Van Leeuwen, T. (2001). Multimodal discourse: the modes and media of contemporary communication. London: Edward Arnold.

[22] Kress, G. \& Van Leeuwen, T. (1996). Reading images: the grammar of visual design. 2nd ed. London: Routledg.

[23] Lahlali, E. (2014). The discourse of Egyptian slogans: from 'Long Live Sir' to 'Down with the Dictator'. Arab Media and Society, 19(1), 1-14.

[24] Lai, M. (2012). The linguistic landscape of Hong Kong after the change of sovereignty. International Journal of Multilingualism, 10, 1-22.

[25] Landry, R. \& Bourhis, R. (1997). Linguistic landscape and ethnolinguistic vitality: an empirical study. Journal of Language and Social Psychology, 16(1), 23-49.

[26] Parisot, J. (2013). American power, East Asian regionalism and emerging powers: in or against empire? Third World Quarterly, 34(7), 1159-1174.

[27] Pennycook, A. \& Makoni, S. (2006). Disinventing and reconstituting languages. In S. Makoni \& A. Pennycook (Eds.), Disinventing and reconstituting languages (1-41). Cleveden, Buffalom, and Toronto: Multilingual Matters.

[28] Reh, M. (2004). Multilingual writing: a reader-oriented typology -with examples from Lira Municipality (Uganda). International Journal of the Sociology of Language, 170, 1-41.

[29] Rozenholc, C. (2010). The neighborhood of Florentin: a window to the globalization of Tel Aviv. Journal of Urban and Regional Analysis, 2(2), 81-95.

[30] Ryding, K.C. (2005). A reference grammar of Modern Standard Arabic. Cambridge: Cambridge University Press.

[31] Saraceni, M. (2010). The Relocation of English: Shifting Paradigms in a Global Era. Basingstoke: Palgrave Macmillan.

[32] Scollon, R. (1997). Handbills, tissues, and condoms: a site of engagement for the construction of identity in public discourse. Journal of Sociolinguistics, 1 (1), 39-61.

[33] Scollon, R. \& Scollon, S. (2003). Discourses in Place: Language in the Material World. London and New York: Routledge.

[34] Seals, C.A. (2013) Creating a landscape of Dissent in Washington, DC. In C. Helot, M. Barni, R. Janssens \& C. Bagna (Eds.), Linguistic landscapes, multilingualism and social change, pp. 53-68.

[35] Sebba, M. (2010). Review of linguistic landscapes: a comparative study of urban multilingualism in Tokyo. Writing System Research 2(1), 73-76.

[36] Seloni, L. \& Sarfati, Y. (2017). Linguistic landscape of Gezi Park protests in Turkey. Journal of Language and Politics, 16(6), $782-808$. 
[37] Sonntag, S. (2003). The local politics of Global English. Case studies in linguistic globalization. Lenham: Lexington Books.

[38] Spolsky, B. \& Cooper, R. (1991). The Languages of Jerusalem. Oxford: Clarendon Press.

[39] Stroud, C. \& Mpendukana, S. (2009). Towards a material ethnography of linguistic landscape: multilingualism, mobility and space in a South African township. Journal of Sociolinguistics, 13, 363-386.

[40] Thibault, P. J. (1991). Social semiotics as praxis: Text, social meaning making, and Nabokov's Ada. Minneapolis: University of Minnesota Press.

[41] Thurlow, C. \& Jaworski, A. (2010). Introducing semiotic landscapes. In C., Thurlow \& A., Jaworski (Eds.), Semiotic Landscapes: Language, Image, Space (1-40). London: Continuum.

[42] Ukeje, C. (2004). From Aba to Ugborodo: gender identity and alternative discourse of social protest among women in the Oil Delta of Nigeria. Oxford Development Studies, 32(4), 605-617.

[43] Woolfson, C. (2006). Discourses of labor protest. Atlantic Journal of Communication, 14(1/2), 70-96.

Ghazi Khaleel Al-Naimat is Assistant Professor of Linguistics in the Department of English Language and Literature at AlHussein Bin Talal University, Jordan. He completed his PhD at the University of Liverpool, UK. His research interests focus on Sociolinguistics, Language Policy and Planning, Linguistic Landscapes, Semantics, Syntax, and Discourse Analysis. He has published a number of papers in English and Arabic Sociolinguistics and other sub-fields of Linguistics. His address details are as follows: P. O. Box 20, Ma’an 71111, Jordan. Emails: ghazinaimat@ahu.edu.jo; ghazinaimat1@ gmail.com. 